\title{
COMMENTARY
}

\section{Fire on the mountain—run boys, run!}

\author{
VERNON C. BLEICH*
}

Department of Natural Resources and Environmental Science, University of Nevada Reno, Mail Stop 186, 1664 North Virginia Street, Reno, NV 89557, USA

*Corresponding Author:vcbleich@gmail.com

Key words: bighorn sheep, California, conflict, habitat enhancement, land management, legislation, litigation, Ovis canadensis, politics, prescribed fire, protected area, wilderness

\begin{abstract}
Perhaps it is time to once again steal fire from the mountain gods and through a great relay, bring fire and the message of disturbance ecology back to the modern-day people of the world.
\end{abstract}

\section{J. Saveland (1995)}

Fire was among several topics dominating the news in 2020, and it received unprecedented coverage in California. As a result, publication of the special issue of California Fish and Wildlife Journal that focused on fire and fire management (Baker et al. 2020) was timely, and it provided the impetus for these comments. As noted by Shaffer (2020) in his introduction to the special issue, native plant and animal communities are greatly impacted in the absence of fire or by greatly altered fire regimes; further, it must be kept in mind that effects of fire management policies on wildlife can be direct or indirect (Shaffer and Laudenslayer 2006). Moreover, there is a continuing need to enhance understanding about ecological systems and their drivers, of which fire is a critically important element (Britting 2020) and, perhaps, second only to water with respect to its ecological influence in California (Shaffer 2020). Thus, topics as diverse as policy and vegetation treatments (Church et al. 2020; Fuller et al. 2020; Green et al. 2020), effects of fire on vegetation (Ayres et al. 2020; Klip et al. 2020; Lindstrand et al. 2020), or impacts or benefits of fire to wildlife or water (Cook and Hayes 2020; Doyle et al. 2020; Williamson and Weckerly 2020) included in the special issue are meaningful and welcomed contributions to the literature on resource conservation and management. Missing from the discussion was an assessment of fire management in the big picture context of wildlife conservation-particularly as it relates to protected areas - and that omission provided the impetus for this commentary.

Shortly before publication of the special issue, Covington and Pyne (2020) offered opinions on wildfire in the contexts of climate change and vegetation management strategies, and noted that wildfire is not, "[a] 'wicked' problem so entangled with scientific and social complexities that solutions are impossible". Despite that optimism, social and political complexities associated with fire or fire management are burdensome - and all-too-frequently 
are impossible - to overcome. Controversy associated with the use of prescribed fire has impacted 'naturalness' outside of, but especially within, legislated wilderness (Christensen 1995; Cole and Landres 1996). Even small projects, such as those advocated by Holl et al. (2012) to help ensure viability and persistence of bighorn sheep (Ovis canadensis) — a USFS sensitive species (USFS 2005) dependent on chaparral habitat in southern California (Light et al. 1966; Holl et al. 1983; Bleich 2010; Bleich et al. 2008, 2019) — can require thousands of pages of analysis (Stemler 2020). Further, the Equal Access to Justice Act (EAJA) provides almost unlimited opportunities to recoup expenses for lawsuits against the federal government (Lofthouse et al. 2014; Baier 2011, 2015). Thus, the EAJA virtually guarantees that any action not to the liking of a special-interest group will be opposed (see, for example, Wilderness Watch 2021) and followed by litigation. Win or lose, the plaintiffs are rewarded and federal reimbursements for legal fees incentivize and encourage subsequent litigation (Mortimer and Malmsheimer 2011).

It is well established by Pyne et al. (1996) and many others that, “... from the earliest times, humans have altered the natural fire regimes [everywhere]", and for thousands of years the number of anthropogenic fires far exceeded those from other causes across much of North America (Kay 2002; Williams 2002). Many issues complicate contemporary fire management (Czech 1996), however, and opposition to the use of fire for fuel reduction or wildlife habitat enhancement became ensconced firmly in the political arena with passage of the Wilderness Act (United States Congress 1964) and subsequent legislation that created obstacles both to prescribed ignitions and fire suppression in those 'protected' areas (Czech 1996). When these obstacles are combined with the likelihood of litigation (Baier 2011, 2015; Lofthouse et al. 2014) or persistent social and institutional barriers (Quinn-Davidson and Varner 2011; Miller and Aplet 2016), they are compounded further by bureaucratic inertia (Grumbine 1990). As a result, the need for clarifications, meaningful decisions, and proactive management is exacerbated.

Ten years after passage of the Wilderness Act the U. S. Forest Service changed its policy from one of fire suppression to one of fire management (DeBruin 1974; see also Pruden and Brennan 1998), yet prescribed fire in Forest Service wilderness occurs infrequently (Stephens and Sugihara 2006), and even more rarely in the chaparral ecosystems of southern California (Holl and Bleich 1983, 2010; Holl et al. 2012). Moreover, annual declines in hectares burned from 1998 to 2018 confirmed long-term downward trends in use of prescribed fire throughout California (Kolden 2019).

The practicality of restoring natural fire regimes in wilderness has been questioned (Husari 1995), but revised policies in place since 1968 in National Park Service wilderness allow some lightning-caused fires to burn if compatible with resource management objectives (Zimmerman and Bunnell 2000; Stephens and Sugihara 2006), and long-term programs are in place in wilderness areas of Yosemite National Park and elsewhere on some lands managed by the U.S. Forest Service (NPS 2004; Husari and McKelvey 1996). Despite these positive steps, the issues and concerns expressed by Covington and Pyne (2020) are timely and appropriate, and also are globally applicable (Kelly et al. 2020; Pickrell and Pennisi 2020).

Changing climates demand new, easily adaptable policies among agencies (Stephens and Ruth 2005), and a debunking of the notion that 'wilderness' necessitates an absence of anthropogenic manipulation (e.g., Grant and Geiger 2021). Interpretations of legislation or policies vary widely among, and even within, land management agencies, but directly impact conservation imperatives inside and outside of wilderness (Bailey 1992; Bleich 
1999a, 1999b, 2005, 2016). Indeed, it is essential that fire management strategies that will enhance ecological integrity and reduce hazardous fuels (Covington and Pyne 2020) be implemented, especially in 'wilderness' proximate to, and in some cases abutting, urbanized areas; among examples are the Lone Peak Wilderness and Twin Peak Wilderness in Utah, and Arizona's Pusch Ridge Wilderness. And, where natural or prescribed fire cannot be an option, mechanical manipulation to facilitate maintenance or restoration of ecosystem processes may be appropriate and receive consideration (Leopold et al. 1963; Green 1977; Bleich and Holl 1982; Parsons and Landres 1998; Bleich 1999a; Miller et al. 2011).

Decisions to use fire or mechanical options in wilderness will be controversial (see, again, Wilderness Watch 2021), must be based on the best possible information (Parsons and Landres 1998), but also will require fundamental changes in how wilderness areas are defined and managed (Cole et al. 2008). The U.S. Congress (1964) constrained management options in wilderness; as a result, only Congress can address issues associated with fire management and its ramifications for wildlife habitat and, ultimately, species conservation therein. This paradox is confounded immensely by wilderness advocates within and outside of federal land management agencies (Bleich 1999a), the increasing likelihood of climate change (Covington and Pyne 2020; Kelly et al. 2020), and an expectation that future climate will enhance conditions favorable to ignitions and subsequent spread of large wildfires (Miller et al. 2011; Yoon et al. 2015; Goss et al. 2020). The prevailing mantra that wilderness must remain inviolate to anthropogenic influences in order to ensure "untrammeled" settings essential to otherwise intangible benefits (Spurr 1966; Larsen 1997; Fredrickson and Anderson 1999; Johnson 2002; Tin 2012; Miller et al. 2020 [but see Corliss \{2019\} and Henderson $\{2020\}]$ ) further complicates fire management, and has enormous, albeit largely negative, implications for wildlife conservation or ecosystem function.

It was almost simultaneously, in 1964, that the Wilderness Act became law and Bob Dylan released his near-prophetic ballad, The Times, They Are a-Changin' (Gray 2006). Since then, shifting environmental conditions have yielded a change in the realized niche of many species (Pineda-Munoz et al. 2021), animal distributions have been altered (Thomas 2010), and conservation priorities have evolved (Parks et al. 2020). Fire regimes are anticipated to change even further (Parks et al. 2018 for review), and mitigation in the form of proactive measures - even in 'protected areas' - has been identified as desirable, or even necessary, to maintain biodiversity and facilitate population connectivity (Hannah 2008; Thomas and Gillingham 2015; Parks et al. 2020; Pineda-Munoz et al. 2021).

Designation of wilderness is an opportunistic political process (Haufler et al. 1996) that historically has reflected a near absence of ecological considerations (Bleich 2005, 2016). Despite widespread environmental change and a realization that proactive intervention on behalf of conservation will become increasingly appropriate, the management of fire and fuels remains a complex issue. It is a problem that crosses traditional disciplinary boundaries, and resolution requires integration of social and biological issues (Conard and Weise 1998; Krausman and Czech 2000; Miller 2006, 2014; Ryan et al. 2013; Krausman 2017).

We must make good decisions about the use of fire, and not just its control (Agee 2006), and there has been some progress (Cole 2019). The special issue (Baker 2020) that spurred this commentary was a welcome contribution to the literature, and fire as a conservation imperative warrants continuing recognition and appropriate application, whether within or outside of wilderness (Zimmerman and Bunnell 2000). There must be increased acceptance that conservation, and especially wildlife conservation, often requires action that 
has been stymied - or even prevented - by the status quo, as exemplified by the extirpation of bighorn sheep from the Pusch Ridge Wilderness (Krausman 2017). Such an acknowledgment will demand a change in human values, however, and create a controversy that can have no technical solution (sensu Hardin 1964). Fire increasingly is recognized as an important ecological component, and an overzealous application of wilderness policies can be detrimental to wildlife conservation objectives (Bailey and Woolever 1992). Indeed, “.... fire must be allowed to play a more prevalent natural role and thus a more natural role in wilderness ecosystems - including in some cases the artificial introduction of prescribed fire to make up for past fire prevention and control or for present suppression on lands adjacent to wilderness" (Schoenfeld and Hendee 1978:107-108).

Managers must consider the human and ecological environments associated with any wilderness area, and how they influence available management options; among the strongest of these likely are anthropogenic patterns of development, and climate (Miller 2006, 2014; Kelly et al. 2020). The time for blame, political gamesmanship, endless planning, and litigation begat by proposed use of fire in the context of conservation has passed (Schoonen 2020), but "science can [only] advise, it cannot decide" (Covington and Pyne 2020). Awareness and vigilance are necessary to assure that public trust resources are managed to benefit the public trust owners (Bailey 2015) and, “... we must work toward a common goal: the sound and productive management of the world's ... ecosystems" (Bleich 1982). To achieve that goal, it is imperative that environmentalists acknowledge that setting aside preserved lands is not the only approach to the protection of ecological values (Franklin 1989), and that, "... the twin goals of noninterference with nature and of preserving pristine natural habitats are incompatible [and] ... that nature reserves can't be left to nature alone to manage" (Diamond 1992). Congress must be made aware of its long history of enacting conflicting environmental legislation and the complications that have resulted therefrom, and make the corrections (Thomas 2004; Bleich 2005, 2016) that currently constrain wildlife conservation on federal lands, especially in wilderness. Absent these requisites, progress toward greater use of prescribed fire - and other public trust issues centered on wildlife conservation - will remain slow and, I suspect, will move forward even more slowly in the future.

\section{ACKNOWLEDGMENTS}

I thank N. G. Andrew, J. A. Bailey, C. E. Brewer, C. W. Epps, V. Geist, K. P. Hurley, G. C. Kerr, P. R. Krausman, K. M. Longshore, G. P. Mulcahy, M. W. Oehler, A. M. Pauli, R. R. Ramey, G. W. Sudmeier, J. D. Wehausen, and J. C. Whiting for participating in many conversations relevant to issues raised in this essay. Special recognition is extended to my late colleagues, J. C. Bicket, S. A. Holl, L. M. Lesicka, D. Racine, R. L. Vernoy, and R. A. Weaver, for sharing opinions and contributing to additional meaningful discussions. R. T. Bowyer, E. M. Rominger, B. P. Wiedmann, and an anonymous reviewer provided comments on the manuscript, and offered helpful suggestions for which I am grateful. This is Professional Paper 137 from the Eastern Sierra Center for Applied Population Ecology.

\section{LITERATURE CITED}

Agee, J. K. 2006. Foreword. Pages xi-xiii in N. G. Sugihara, J. W. van Wagtendonk, K. E. Shaffer, J. Fites-Kaufman, and A. E. Thode, editors. Fire in California's Ecosystems. University of California Press, Berkeley, CA, USA. 
Ayres, D. R., V. Meyer, M. Gogol-Prokurat, and L. Fety. 2020. Survival of the rare Packera layneae (Asteraceae), under chaparral and after fire. Pages 82-91 in A. D. Baker, editor. California Fish and Wildlife Journal—Special Fire Issue. Available from https://nrm.dfg.ca.gov/FileHandler.ashx?DocumentID=184823\&inline (10 December 2020).

Baier, L. E. 2011. Reforming the Equal Access to Justice Act. Pages 29-39 in J. Reneau and J. E. Spring, editors. Records of North American big game. Thirteenth edition. Boone and Crockett Club, Missoula, MT, USA.

Baier, L. E. 2015. Inside the Equal Access to Justice Act: environmental litigation and the crippling battle over America's lands, endangered species, and critical habitats. Rowman and Littlefield Publishers, Lanham, MD, USA.

Bailey, J. A. 1992. Managing bighorn habitat from a landscape perspective. Northern Wild Sheep and Goat Council Proceedings 8:49-57.

Bailey, J. A. 2015. Wildlife, the public trust, and the modern day "Tragedy of the Commons". California Fish and Game 101:200-203.

Bailey, J. A., and M. M. Woolever. 1992. Determining the future of bighorn herds in wilderness areas. Northern Wild Sheep and Goat Council Proceedings 8:121-135.

Baker, A. D. (Editor). 2020. California Fish and Wildlife Journal-Special Fire Issue. Available from: https://nrm.dfg.ca.gov/FileHandler.ashx?DocumentID=184823\&inline (10 December 2020).

Bleich, V. C. 1982. Review comments. Pages 567-568 in C. E. Conrad and W. C. Oechel, technical coordinators. Proceedings of the symposium on the dynamics and management of Mediterranean-type ecosystems. General Technical Report PSW-58. U.S. Department of Agriculture, Forest Service, Pacific Southwest Forest and Range Experiment Station, Berkeley, CA, USA.

Bleich, V. C. 1999a. America's wilderness. National Geographic Magazine 195(3):xv.

Bleich, V. C. 1999b. Wildlife conservation and wilderness management: uncommon objectives and conflicting philosophies. North American Wild Sheep Conference Proceedings 2:195-205.

Bleich, V. C. 2005. Politics, promises, and illogical legislation confound wildlife conservation. Wildlife Society Bulletin 33:66-73.

Bleich, V. C. 2010. Development of the Cushenbury South Quarry: potential environmental impacts to Nelson's bighorn sheep and suggested mitigation. ESCAPE Technical Report 2010(1):1-48. Eastern Sierra Center for Applied Population Ecology, Bismarck, ND, USA.

Bleich, V. C. 2016. Wildlife conservation and wilderness: wishful thinking? Natural Areas Journal 36:202-206.

Bleich, V. C., and S. A. Holl. 1982. Management of chaparral habitat for mule deer and mountain sheep in southern California. Pages 247-254 in C. E. Conrad and W. C. Oechel, technical coordinators. Proceedings of the symposium on the dynamics and management of Mediterranean-type ecosystems. General Technical Report PSW-58. U.S. Department of Agriculture, Forest Service, Pacific Southwest Forest and Range Experiment Station, Berkeley, CA, USA.

Bleich, V. C., M. E. Blum, K. T. Shoemaker, D. Sustaita, and S. A. Holl. 2019. Habitat selection by bighorn sheep in a mesic ecosystem: the San Rafael Mountains, California, USA. California Fish and Game 105:205-224. 
Bleich, V. C., H. E. Johnson, S. A. Holl, L. Konde, S. G. Torres, and P. R. Krausman. 2008. Fire history in a chaparral ecosystem: implications for conservation of a native ungulate. Rangeland Ecology and Management 61:571-579.

Britting, S. 2020. Introduction — continued. Pages 11-12 in A. D. Baker, editor. California Fish and Wildlife Journal-Special Fire Issue. Available from https://nrm.dfg. ca.gov/FileHandler.ashx?DocumentID=184823\&inline (10 December 2020).

Christensen, N. L. 1995. Fire and wilderness. International Journal of Wilderness 1(1):30 34.

Church, K., A. Arevalo, and L. McFarlane. 2020. CalTrans' efforts to reduce the frequency and severity of wildfires while protecting California's valuable resources. Pages 52-56 in A. D. Baker, editor. California Fish and Wildlife Journal-Special Fire Issue. Available from https://nrm.dfg.ca.gov/FileHandler. ashx?DocumentID=184823\&inline (10 December 2020).

Cole, D. N. 2019. Community and fire ecologists, park biologists, and recreation scientists: the antecedents of wilderness science. International Journal of Wilderness 26(3):52-66.

Cole, D. N., and P. B. Landres. 1996. Threats to wilderness ecosystems: impacts and research needs. Ecological Applications 6:168-184.

Cole, D. N., and 15 coauthors. 2008. Naturalness and beyond: protected area stewardship in an era of global environmental change. George Wright Forum 25:36-56.

Conard, S. G., and D. R. Weise. 1998. Management of fire regime, fuels, and fire effects in southern California chaparral: lessons from the past and thoughts for the future. Tall Timbers Fire Ecology Conference Proceedings 20:342-350.

Cook, D. G., and M. P. Hayes. 2020. Post-fire species composition and abundance of a lenticbreeding amphibian assemblage: case study of Ledson Marsh. Pages 110-128 in A. D. Baker, editor. California Fish and Wildlife Journal—Special Fire Issue. Available from https://nrm.dfg.ca.gov/FileHandler.ashx?DocumentID=184823\&inline (10 December 2020).

Corliss, J. 2019. White wilderness: race, capitalism, and alternative knowledges of natural space. Thesis, DePaul University, Chicago, IL, USA.

Covington, W. W., and S. Pyne. 2020. Fire in our future. Science 370(6512):13.

Czech, B. 1996. Challenges to establishing and implementing sound natural fire policy. Renewable Resources Journal 14(2):14-19.

DeBruin, H. W. 1974. From fire control to fire management: a major policy change in the Forest Service. Tall Timbers Fire Ecology Conference Proceedings 14:11-17.

Diamond, J. 1992. Must we shoot deer to save nature? Natural History 101(8):2-8.

Doyle, J. M., M. Bogdan, and J. R. Olson. 2020. Analysis of the impacts of the Soberanes Wildfire on stream ecosystems. Pages 129-147 in A. D. Baker, editor. California Fish and Wildlife Journal-Special Fire Issue. Available from https://nrm.dfg. ca.gov/FileHandler.ashx?DocumentID=184823\&inline (10 December 2020).

Franklin, J. F. 1989. Toward a new forestry. American Forests 95 (Nov-Dec):37- 44.

Fredrickson, L. M., and D. H. Anderson. 1999. A qualitative exploration of the wilderness experience as a source of spiritual inspiration. Journal of Environmental Psychology 19:21-39.

Fuller, A., L. Rachowicz, and H. Blair. 2020. The California Vegetation Treatment Program: integrating biological resource protection into wildfire risk reduction. Pages 46-51 in A. D. Baker, editor. California Fish and Wildlife Jour- 
nal-Special Fire Issue. Available from https://nrm.dfg.ca.gov/FileHandler. ashx?DocumentID=184823\&inline (10 December 2020).

Goss, M., D. L. Swain, J. T. Abatzoglou, A. Sarhadi, C. A. Kolden, A. P. Williams, and N. S. Diffenbaugh. 2020. Climate change is increasing the likelihood of extreme autumn wildfire conditions across California. Environmental Research Letters 15:094016

Grant, R., and A. Geiger. 2021. The lost history of Yellowstone: debunking the myth that the great national park was a wilderness untouched by humans. Smithsonian 51(9):32-55,116-117.

Gray, M. 2006. The Bob Dylan Encyclopedia. Continuum International Publishing Group, New York, NY, USA.

Green, K., M. Tukman, D. Loudon, A. Schichtel, K. Gaffney, and M. Clark. 2020. Sonoma County Complex Fires of 2017: remote sensing data and modeling to support ecosystem and community resiliency. Pages $14-45$ in A. D. Baker, editor. California Fish and Wildlife Journal-Special Fire Issue. Available from https://nrm. dfg.ca.gov/FileHandler.ashx?DocumentID=184823\&inline (10 December 2020).

Green, L. R. 1977. Fuel reduction without fire - current technology and ecosystem impact. Pages $163-171$ in H. A. Mooney, and C. E. Conrad, technical coordinators. Proceedings of the symposium on the consequences of fire and fuel management in Mediterranean ecosystems. General Technical Report WO-3. U.S. Department of Agriculture, Forest Service, Pacific Southwest Forest and Range Experiment Station, Berkeley, CA, USA.

Grumbine, R. E. 1990. Viable populations, reserve size, and federal lands management: a critique. Conservation Biology 4:127-134.

Hannah, L. 2008. Protected areas and climate change. Annals of the New York Academy of Sciences 1134:201-212.

Hardin, G. 1968. The tragedy of the commons. Science 162(3859):1243-1248.

Haufler, J. B., L. G. Adams, R. G. Brocke, M. J. Conroy, G. Joslin, and K. G. Smith. 1996. Wildlife management in North American wilderness. Wildlife Society Technical Review 96-1. The Wildlife Society, Bethesda, MD, USA. Available from: https:// wildlife.org/technical-reviews/ (2 January 2021).

Henderson, L. A. 2020. Ain't no love in the heart of the mountains: hip-hop, exclusion, and the white wilderness. Thesis, Humboldt State University, Arcata, CA, USA.

Holl, S. A., and V. C. Bleich. 1983. San Gabriel mountain sheep: biological and management considerations. U.S. Forest Service, San Bernardino National Forest, San Bernardino, CA, USA.

Holl, S. A., and V. C. Bleich. 2010. Responses of large mammals to fire and rain in the San Gabriel Mountains, California. Northern Wild Sheep and Goat Council Proceedings 17:139-156.

Holl, S. A., V. C. Bleich, B. W. Callenberger, and B. Bahro. 2012. Simulated effects of two fire regimes on bighorn sheep: the San Gabriel Mountains, California, USA. Fire Ecology 8(3):88-103.

Husari, S. J. 1995. Fire management in small wilderness areas and parks. Pages 117-120 in J. K. Brown, R.W. Mutch, C. W. Spoon, and R. H. Wakimoto, technical coordinators. Symposium on fire in wilderness and park management. General Technical Report INT-GTR-320. U.S. Department of Agriculture, Forest Service, Intermountain Research Station, Ogden, UT, USA. 
Husari, S. J., and K. S. McKelvey. 1996. Fire-management policies and programs. Pages 1101-1114 in Sierra Nevada Ecosystem Project: final report to Congress. Volume II. Assessments and scientific basis for management options. Centers for Water and Wildland Resources, University of California, Davis, CA, USA.

Johnson, B. 2002. On the spiritual benefits of wilderness. International Journal of Wilderness 8(3):28-32.

Kay, C. E. 2002. False gods, ecological myths, and biological reality. Pages 238-261 in C. E. Kay and R. T. Simmons, editors. Wilderness and political ecology: aboriginal influences and the original state of nature. University of Utah Press, Salt Lake City, UT, USA.

Kelly, L. T., and 26 coauthors. 2020. Fire and biodiversity in the Anthropocene. Science 370(6519):929-939.

Klip, J. M. K., M. R. Caldwell, D. R. Ayres, and V. Meyer. 2020. Effects of a firebreak on plants and wildlife at Pine Hill, a biodiversity hotspot, El Dorado County, California. Pages 58-81 in A. D. Baker, editor. California Fish and Wildlife Journal-Special Fire Issue. Available from https://nrm.dfg.ca.gov/FileHandler. ashx? DocumentID=184823\&inline (10 December 2020).

Kolden, C. A. 2019. We're not doing enough prescribed fire in the western United States to mitigate wildfire risk. Fire 2019:2,30. DOI:10.3390/fire2020030.

Krausman, P. R. 2017. And Then There Were None: The Demise of Desert Bighorn Sheep in the Pusch Ridge Wilderness. University of New Mexico Press, Albuquerque, NM, USA.

Krausman, P. R., and B. Czech. 2000. Wildlife management activities in wilderness areas of the southwestern United States. Wildlife Society Bulletin 28:550-557.

Larsen, D. L. 1997. Fulfilling the NPS mission. National Park Service interpretive development program module 101. USDI National Park Service, Washington, D.C., USA. Available from https://www.nps.gov/idp/interp/101/lesplan.htm (26 December 2020).

Leopold, A. S., S. A. Cain, C. M. Cottam, I. N. Gabrielson, and T. L. Kimball. 1963. Wildlife management in the national parks [1969 reprint]. Administrative policies for natural areas of the national park system. U.S. Department of the Interior, National Park Service, Washington, D.C., USA. Available from http://npshistory. com/publications/leopold_report.pdf (28 December 2020).

Light, J. T., T. R. Zrelak, and H. Graham. 1966. San Gorgonio bighorn habitat management plan. U.S. Department of Agriculture, Forest Service, San Bernardino National Forest, San Bernardino, CA, USA.

Lindstrand III, L., J. A. Kierstead, and D. W. Taylor. 2020. Post-wildfire response of Shasta snow-wreath. Pages 92-98 in A. D. Baker, editor. California Fish and Wildlife Journal-Special Fire Issue. Available from https://nrm.dfg.ca.gov/FileHandler. ashx?DocumentID=184823\&inline (10 December 2020).

Lofthouse, J. R., M. Yonk, and R. T. Simmons. 2014. Equal Access to Justice Act. Strata Policy, Logan, UT, USA. Available from https://strata.org/pdf/2014/equal-accessjustice.pdf (4 November 2020).

Miller, C. 2006. Wilderness fire management in a changing world. International Journal of Wilderness 12(1):18-21,13.

Miller, C. 2014. The contribution of natural fire management to wilderness fire science. 
International Journal of Wilderness 20(2):20-25.

Miller, C., J. Abatzoglou, J. Brown, and A. D. Syphard. 2011. Wilderness fire management in a changing environment. Pages 269-294 in D. McKenzie, D. Falk, and C. Miller, editors. The landscape ecology of fire. Springer, London, United Kingdom.

Miller, C., and G. H. Aplet. 2016. Progress in wilderness fire science: embracing complexity. Journal of Forestry 114:373-383.

Miller, Z. D., W. L. Rice, P. Newman, B. D. Taff, J. Gottschalk, C. Meyer, and J. A. Beeco. 2020. Pavement treatment type influences visitor experiences related to vehicular road sound in Death Valley National Park. Journal of Ecotourism (online). DOI:1 $0.1080 / 14724049.2020 .1856856$.

Mortimer, M. J., and R. W. Malmsheimer. 2011. The Equal Access to Justice Act and US Forest Service land management: incentives to litigate? Journal of Forestry 109:352-358.

NPS (National Park Service). 2004. Yosemite fire management plan/environmental impact statement. Available from https://www.nps.gov/yose/learn/nature/fuelsmanagement.htm (3 March 2021).

Parks, S. A., L. M. Holsinger, C. Miller, and M.-A. Parisien. 2018. Analog-based fire regime and vegetation shifts in mountainous regions of the western US. Ecography 41:910-921.

Parks, S. A., C. Carroll, S. Z. Dobrowski, and B. W. Allred. 2020. Human land uses reduce climate connectivity across North America. Global Change Biology 26:29442955.

Parsons, D. J., and P. B. Landres. 1998. Restoring natural fire to wilderness: how are we doing? Tall Timbers Fire Ecology Conference Proceedings 20:366-373.

Pickrell, J., and E. Pennisi. 2020. Record U.S. and Australian fires raise fears for many species. Science 370(6512):18-19.

Pineda-Munoz, S., Y. Wang, S. K. Lyons, A. B. Toth, and J. L. McGuire. 2021. Mammal species occupy different climates following the expansion of human impacts. Proceedings of the National Academy of Sciences 118(2):1-9.

Pruden, T. L., and L. A. Brennan (editors). 1998. Fire in ecosystem management: shifting the paradigm from suppression to prescription. Proceedings of the 20th Tall Timbers Fire Ecology Conference. Tall Timbers Research Station, Tallahassee, FL, USA.

Pyne, S. J., P. L. Andrews, and R. D. Laven. 1996. Introduction to Wildland Fire. Second edition. James Wiley and Sons, New York, NY, USA.

Quinn-Davidson, L. N., and J. M. Varner. 2011. Impediments to prescribed fire across agency, landscape and manager: an example from northern California. International Journal of Wildland Fire 21:210-218.

Ryan, K. C., E. E. Knapp, and J. M. Varner. 2013. Prescribed fire in North American forests and woodlands: history, current practice, and challenges. Frontiers in Ecology and the Environment 2013, 11:e15-e24. DOI: 10.1890/120329.

Saveland, J. 1995. Fire in the forest. Pages 14-19 in L. G. Eskew, compiler. Proceedings of the 1995 National Silviculture Workshop, Mescalero, New Mexico. General Technical Report RM-GTR-267. U.S. Department of Agriculture, Forest Service, Rocky Mountain Forest and Range Experiment Station, Fort Collins, CO, USA.

Schoenfeld, C. A., and J. C. Hendee. 1978. Wildlife Management in Wilderness. Boxwood 
Press, Pacific Grove, CA, USA.

Schoonen, T. 2020. Wildfires spotlight need for forest management. B\&C Club News. Boone and Crockett Club, Missoula, MT, USA. Available from https://www. boone-crockett.org/news (31 December 2020).

Shaffer, K. E. 2020. Introduction. Pages 9-10 in A. D. Baker, editor. California Fish and Wildlife Journal-Special Fire Issue. Available from https://nrm.dfg.ca.gov/FileHandler.ashx?DocumentID=184823\&inline (10 December 2020).

Shaffer, K. E., and W. F. Laudenslayer, Jr. 2006. Fire and animal interactions. Pages 118 144 in N. G. Sugihara, J. W. van Wagtendonk, K. E. Shaffer, J. Fites-Kaufman, and A. E. Thode, editors. Fire in California's ecosystems. University of California Press, Berkeley, CA, USA.

Spurr, S. H. 1966. Wilderness management. The Horace M. Albright Lecture in Conservation 6:1-17. University of California, School of Natural Resources, Berkeley, CA, USA.

Stemler, J. 2020. Restoring forest health - the Boone and Crockett Club is leading policy efforts to implement active forest management projects. Fair Chase 36(4):28-31.

Stephens, S. L., and L. W. Ruth. 2005. Federal forest fire policy in the United States. Ecological Applications 15:532-542.

Stephens, S. L., and N. G. Sugihara. 2006. Fire management and policy since European settlement. Pages 431-443 in N. G. Sugihara, J. W. van Wagtendonk, K. E. Shaffer, J. Fites-Kaufman, and A. E. Thode, editors. Fire in California's ecosystems. University of California Press, Berkeley, CA, USA.

Thomas, C. D. 2010. Climate, climate change and range boundaries. Diversity and Distributions 16:488-495.

Thomas, C. D., and P. K. Gillingham. 2015. The performance of protected areas for biodiversity under climate change. Biological Journal of the Linnean Society 115:718 730.

Thomas, J. W. 2004. The management of the federal lands: where now? Fair Chase 19(2): 12 .

Tin, T. 2012. Wilderness spirituality. International Journal of Wilderness 18(1):3,24.

United States Congress. 1964. Wilderness Act. 88th Congress of the United States, Second Session, Washington, DC, USA.

USFS (United States Forest Service). 2005. Final environmental impact statement, Volume 2. Land management plans: Angeles National Forest, Cleveland National Forest, Los Padres National Forest, San Bernardino National Forest. USDA Forest Service R5-MB-074-B. Pacific Southwest Region, Vallejo, California, USA.

Wilderness Watch. 2021. Say no to a plan to burn and poison wildernesses in Arizona. Wilderness Watch, Missoula, MT, USA. Available from: https://wildernesswatch. salsalabs.org/blm-burn-poison-6-wildernesses-az?wvpId=2dcfdc40-6332-47cea63e-e2af20b4af88 (2 January 2021).

Williams, G. W. 2002. Aboriginal use of fire: are there any "natural" plant communities? Pages 179-214 in C. E. Kay and R. T. Simmons, editors. Wilderness and political ecology: aboriginal influences and the original state of nature. University of Utah Press, Salt Lake City, UT, USA.

Williamson, L. H., and F. W. Weckerly. 2020. Elk forage response to prescribed fire in Boyes Meadow, Prairie Creek Redwoods State Park, California. Pages 100-109 in A. D. Baker, editor. California Fish and Wildlife Journal-Special Fire Issue. Avail- 
able from https://nrm.dfg.ca.gov/FileHandler.ashx?DocumentID=184823\&inline (10 December 2020).

Yoon, J.-H., S.-Y. S. Wang, R. R. Gillies, L. Hipps, B. Kravitz, and P. J. Rasch. 2015. Extreme fire season in California: a glimpse into the future? Bulletin of the American Meteorological Society 96(S):5-9.

Zimmerman, G. T., and D. L. Bunnell. 2000. The federal wildland policy: opportunities for wilderness fire management. Pages $288-297$ in D. N. Cole, S. F. McCool, W. T. Borrie, and J. O'Loughlin, compilers. Wilderness science in a time of change conference: wilderness ecosystems, threats, and management. Proceedings RMRSP-15-VOL-5. U.S. Department of Agriculture, Forest Service, Rocky Mountain Research Station, Ogden, UT, USA.

Submitted 10 January 2021

Accepted 2 March 2021

Associate Editor was A. Baker 